\title{
Assessment of the contamination of marine fauna by chlordecone in Guadeloupe and Martinique (Lesser Antilles)
}

\author{
Dromard Charlotte ${ }^{1,{ }^{*}}$, Bodiguel Xavier ${ }^{2}$, Lemoine Soazig ${ }^{1}$, Bouchon-Navaro Yolande ${ }^{1}$, \\ Reynal Lionel ${ }^{2}$, Thouard Emmanuel ${ }^{2}$, Bouchon Claude ${ }^{1}$
}

${ }^{1}$ UMR BOREA CNRS-7208, IRD-207, MNHN, UPMC, UCBN, Université des Antilles et de la Guyane, DYNECAR, Campus de Fouillole, BP 592, 97159, Pointe-à-Pitre, France

${ }^{2}$ IFREMER, Station du Robert, 79 Pointe Fort, 97231, Le Robert, France

*Corresponding author : Charlotte Dromard, email address : cdromard@univ-ag.fr

\begin{abstract}
:
Chlordecone is an organochlorine pesticide, used in the Lesser Antilles from 1972 to 1993 to fight against a banana weevil. That molecule is very persistent in the natural environment and ends up in the sea with runoff waters. From 2003 to 2013, seven campaigns of samplings have been conducted to evaluate the level of contamination of fish, crustaceans, and mollusks. The present study is the first assessment and the first comparison of the concentrations of chlordecone between marine areas, taxonomic groups, and ecological factors like trophic groups or preferential habitat of fish species. The four most contaminated marine areas are located downstream the contaminated rivers and banana plantations. Crustaceans seemed to be more sensitive to the contamination than fish or mollusks. Finally, when comparing contamination of fish according to their ecology, we found that fish usually living at the border of mangrove and presenting detritivores-omnivores diets were the most contaminated by chlordecone. These results are particularly useful to protect the health of the local population by controlling the fishing and the commercialization of seafood products, potentially contaminated by chlordecone.
\end{abstract}

Keywords: Chlordecone, Organochlorine pollution, Marine fauna, Contamination, Guadeloupe, Martinique 


\section{Introduction}

Guadeloupe and Martinique are two overseas French territories located in the Lesser Antilles. Even if the production dramatically decreased over time, the production of bananas represents one of the principal economical activity in both islands, with $260000 \mathrm{t}$ of bananas commercialized in 2010. Indeed, in Guadeloupe, the production of bananas have been halved in 25 years (data from the French Minister of Agriculture). Banana plants grow on volcanic soils, which are located in the northeast of Martinique and the southeast of Guadeloupe. Intensive banana farming leads to an increased vulnerability of crops to parasites and to the use of large amounts of pesticide to eradicate them. Thus, to control the banana weevil Cosmopolites sordidus, an organochlorine insecticide called chlordecone (commercialized as Curlone or Kepone) was used in the French West Indies since 1972. After 20 years, in 1993, the use of chlordecone was definitively banned in all French territories. This molecule is very persistent in the environment where it can induce a wide range of pathology on birds and mammals, like reproductive impairment or neurotoxicity (Epstein 1978; Huff and Gerstner 1978). Kepone is also carcinogenic in rats and mice (Epstein 1978). More recently, the correlation between chlordecone exposure and risk of prostate cancer has been demonstrated for human (Multigner et al. 2010). In 2009, the chemical was included on the list of priority pollutants by the Stockholm Convention.

Despite high rainfall on the two islands during the wet season, a study on the persistence of chlordecone in volcanic soils, based on a leaching model, indicated that the pollution would last for several decades for nitisol, centuries for ferrasol and half a millennium for andosol (Cabidoche et al. 2009). Approximately 6200 ha in Guadeloupe and 12000 ha in Martinique are moderately to heavily polluted by chlordecone, which represents about $25 \%$ of the land surface used for agriculture in each island. Organochlorine molecules are hydrophobic and adsorbed onto organic matter of the soil. With the erosion of soil particles, desorption phenomena, low solubility and infiltration processes, these compounds reach ground waters as well as many small streams that flow directly into the sea (Coat et al. 2006).

The first assessment of the contamination in the French Antilles has been demonstrated in soil and aquatic organisms from the rivers (Snegaroff 1977; Kermarrec 1980). Others studies evidenced the contamination of the suspended organic matter and sediments from rivers (Bocquené 2002; Bocquené and Franco 2005). Bocquené (2002) described for the first time the contamination by chlordecone of two marine species in Martinique (Acanthurus bahianus and Panulirus argus). Coat et al. (2006) completed these data in analyzing 11 other marine species in Martinique. In Guadeloupe, the first evaluation of marine contamination was conducted in 2003 (Bouchon and Lemoine 2003). Marine research on chlordecone pollution has then increased and several reports have been published between 2008 and 2013 (Bouchon and Lemoine 2007; Bertrand et al. 2009, 2010, 2013), especially because the European Commission of Food Safety set the maximal residue limit (MRL) to $20 \mu \mathrm{g} \cdot \mathrm{kg}^{-1}$ wet weight in 2008, while the threshold value was $200 \mu \mathrm{g} \cdot \mathrm{kg}^{-1}$ wet weight before this date. Moreover, seafood products represent a large part of the local gastronomy in the Lesser Antilles. Fisheries activities produce 1800 and 4000 tons of fish per year in Martinique and Guadeloupe, respectively (data from the fishery information system of French Research Institute for Exploitation of the Sea).

Previous studies on the contamination of marine fauna described the level of chlordecone per fish species and per marine areas, in order to rule the fishing activities and protect the local population from this pollution. However, few studies have been done on the ecology of marine species to explain their level of contamination (Bodiguel et al. 2011; Salvat et al. 2012). This approach is essential to understand the transfer of the molecule in the trophic food web and identify the "niches of pollution". 
In the present study, we assessed the contamination of marine fauna by chlordecone gathering ten years of data (2003-2013). We wondered if the concentrations of chlordecone vary according to geographic areas, species, or ecology of marine species like diet or preferential habitats. To do so, all the results of the analyses of chlordecone in marine fauna were compiled in a database and then compared between different geographical and ecological factors.

\section{Materials and Methods}

\subsection{Study sites}

The assessment of the contamination of marine fauna by chlordecone has been conducted in Guadeloupe $\left(16^{\circ} 15^{\prime} \mathrm{N} ; 61^{\circ} 34^{\prime} \mathrm{W}\right)$ and Martinique $\left(14^{\circ} 37^{\prime} \mathrm{N} ; 61^{\circ} 00^{\prime} \mathrm{W}\right)$, Lesser Antilles (Fig. 1). To evaluate the level of contamination around the two islands, samples were collected spatially taking into account areas previously considered for the implementation of the EU Water Framework Directive. These marine sectors have been described as homogeneous water masses according to various criteria as the morphology of the coasts, hydrology or hydrodynamic conditions (Fig. 1). Eleven marine sectors in Guadeloupe and ten in Martinique were considered to compare the contamination of marine fauna according to the geographical location of the samplings.

\subsection{Samplings and database}

Seven sampling campaigns of marine organisms were realized since 2003 (2003, 2007, 2008, 2009, 2010, 2011 and 2013) by different offices: the Department of Food, Agriculture and Forests, the Department of Environment, Land settlement and Housing, the University Antilles-Guyane (UAG) and the French Research Institute for Exploitation of the Sea (Ifremer). During those surveys, 170 species of fish, crustaceans and mollusks were collected around the two islands with the help of fishers. Animals were dissected, conditioned in aluminum foil and kept frozen until analyses. Samples were prepared by taking out the filet with the skin for fish, the abdominal muscle for crustaceans and the total flesh for mollusks, from at least three specimens having the same characteristics (species, size class and geographical origin).

Each sample was characterized by its scientific name, its geographical location (GPS coordinates), its trophic group and preferential habitat (Online Resources 1 and 2).

Six trophic groups of fishes were used: herbivorous (HB), omnivorous-detritivores (OMNIDET), planktivores (PK), carnivores 1 (C1: invertebrate feeders), carnivores 2 (C2: invertebrate and fish feeders) and piscivores (PV: top predator). Even if the fishes can move, five preferential habitats were described and assigned to each species: soft bottoms (including sand and seagrass beds), mangrove borders, coral reefs, coastal water column and open sea (i.e. pelagic species that realized trophic incursions in the coastal ecosystems).

With all information collected, a database including 2781 samples (1431 in Guadeloupe and 1350 in Martinique) was created. 


\subsection{Analyses of the concentrations of chlordecone}

Three laboratories, registered by the French food and safety authorities (ANSES), realized the quantitative analyses: Laboratoire Départemental de la Drôme (LDA26), Laboratoire Départemental de la Sarthe (LDA72) and Idhesa (Labocea).

Molecules of chlordecone were extracted from homogenized samples tissues with a solution of organic solvents (hexane-acetone or pentane-acetone). Appropriate clean-up of the extracts were then performed (Florisil purification), before solvent evaporation. According to the laboratory, two methods were used to measure concentrations of chlordecone. The first method quantified chlordecone by GC-ECD (Gas Chromatography with Electron Capture Detection). With this method, the limit of quantification was $5 \mu \mathrm{ggg}^{-1}$ (wet weight). The second method measured chlordecone with liquid chromatography coupled to mass spectrometry (HPLC-MS/MS). The lower quantification limit with this method was $3 \mu \mathrm{g}_{\mathrm{kg}}{ }^{-1}$ (wet weight). Concentrations of chlordecone were determined following the methods recommended by ANSES (French food and safety authorities) and the three laboratories used the same method of quantification. Concentrations of chlordecone in animal tissues were expressed in $\mu \mathrm{g} \cdot \mathrm{kg}^{-1}$ of wet weight.

\subsection{Statistical analyses}

Data were tested for normality with the Shapiro-Wilk's test. Concentrations of chlordecone were compared between marine areas, year of sampling, diet of organisms and preferential habitats using analyses of variance (ANOVAs). When differences were found with ANOVAs, Tukey's honestly significant difference (HSD) post hoc test were used to perform multiple comparisons. All statistical analyses were performed using the program R.

\section{Results}

\subsection{Comparison of concentrations between geographic areas and taxonomic groups}

Concentrations of chlordecone measured in fish, crustaceans and mollusks have been compared between the different marine areas in which they were collected (Fig. 1). The detail of mean concentration per fish species and per marine sectors is given in Online Resources 1 and 2.

In Guadeloupe, 1046 samples of fish were compared according to eleven marine sectors. The contamination of fish samples was significantly different according to the marine areas in which fish were collected (ANOVA, $F_{(10,1035)}=12.4, p<0.0001$ ). Fish were particularly contaminated in zones $\mathrm{G} 01$ and $\mathrm{G} 02$, where $48 \%$ and $56 \%$ of fish samples, respectively, presented a concentration of chlordecone superior to $20 \mu \mathrm{g} \mathrm{kg}^{-1}$. Mean concentrations of chlordecone $\left( \pm\right.$ SE) measured in fish were $80.9 \pm 20.5 \mu \mathrm{g} \cdot \mathrm{kg}^{-1}$ in zone $\mathrm{G} 01$ and $69.6 \pm 10.2$ $\mu \mathrm{g} . \mathrm{kg}^{-1}$ in zone G02 (Table 1). These two zones differed from the other ones due to the high concentrations of chlordecone measured in fish samples (Tukey HSD, all $p<0.05$ ). The same trend was observed for mollusks (ANOVA, $F_{(9,140)}=5.5, p<0.05$ ). The contamination of mollusks was restricted to zones $\mathrm{G} 01$ and $\mathrm{G} 02$, with mean concentrations ( $\pm \mathrm{SE}$ ) equal to

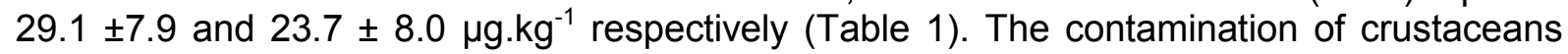
was also significantly different according to marine areas (ANOVA, $F_{(9,232)}=8.1, p<0.05$ ). The most contaminated crustaceans were found in zone G02 with a mean concentration of chlordecone equal to $94.1 \pm 19.2 \mu \mathrm{g} \cdot \mathrm{kg}^{-1}$.

In Martinique, the contamination of fish was maximal in zones M01 and M07 (57.6 \pm 9.5 and $68.2 \pm 10.5 \mu \mathrm{g} \cdot \mathrm{kg}^{-1}$ respectively; Table 2 ) and these two zones differed significantly from 
others marine areas in terms of concentrations of chlordecone (ANOVA, $F_{(9,797)}=11.0, p<$ 0.0001). In zones $\mathrm{M} 01$ and $\mathrm{M} 07,51 \%$ and $58 \%$ of fish samples respectively had a concentration of chlordecone higher than $20 \mu \mathrm{g} \cdot \mathrm{kg}^{-1}$. The mean contamination of chlordecone in crustaceans was high in zone M01, with a mean value equal to $732.7 \pm$ $689.0 \mu \mathrm{g} \cdot \mathrm{kg}^{1}$ (ANOVA, $\mathrm{F}_{(9,519)}=2.4, \mathrm{p}<0.01$ ). However, the concentration of one sample of Callinectes was particularly high in this area $\left(15200 \mu \mathrm{g} \cdot \mathrm{kg}^{-1}\right)$, leading to the extreme mean concentration. No significant difference of contamination was found between mollusks of the different marine areas, but the number of samples was low $(n=25)$.

\subsection{Comparison of concentrations between trophic groups of fishes}

The contamination of fishes was compared between six trophic groups (Fig. 2). To avoid bias linked to spatial variations of the contamination, only fish samples collected in the most contaminated sectors (G01, G02, M01, M07) were selected for these comparisons. Moreover, as the contamination of fish was not different according to the year of sampling (ANOVA, $F_{(6,736)}=5.8, p=0.34$ ), no temporal variations of the fish contamination was noticed between 2003 and 2013.

The contamination of fishes was significantly different according to the trophic groups (ANOVA, $\left.F_{(5,733)}=18.2, p<0.0001\right)$. With a mean concentration $( \pm S E)$ of chlordecone equal to $156.4 \pm 7.4 \mu \mathrm{g} \cdot \mathrm{kg}^{-1}$, detritivores were the most contaminated fishes and differed significantly from the other trophic groups (Tukey's HSD, all $p<0.05$ ). Indeed, high concentrations of chlordecone were measured in samples of Oreochromis mossambicus (maximal concentration: $1036 \mu \mathrm{g} \cdot \mathrm{kg}^{-1}$ ), Mugil cephalus $\left(705 \mu \mathrm{g} \cdot \mathrm{kg}^{-1}\right.$ ) and Mugil curema (690 $\left.\mu \mathrm{g} . \mathrm{kg}^{-1}\right)$. Instead of their trophic level, that can be also due to their sampling from the mangrove ecosystem (see below). Planktivores, carnivores 2 and piscivores constituted a second group, characterized by an intermediate level of contamination (mean concentrations \pm SE: $57.5 \pm 4.2 ; 67.4 \pm 14.9$ and $55.9 \pm 3.7 \mu \mathrm{g} . \mathrm{kg}^{-1}$ respectively). Finally, herbivores and carnivores 1, as Acanthurus bahianus, Haemulon plumierii or Mulloidichthys martinicus, were the less contaminated trophic group with mean concentrations ( $\pm S E$ ) equal to $10.4 \pm 4.6$ for herbivores and $33.2 \pm 11.2 \mu \mathrm{g} . \mathrm{kg}^{-1}$ for carnivores 1 (Fig. 2).

\subsection{Comparison of concentrations between preferential habitats of fishes}

Concentrations of chlordecone were compared between fishes according to their preferential habitat (Fig. 3). The contamination of fishes was different according to their habitat (ANOVA, $\left.F_{(4,734)}=29.3, p<0.0001\right)$. Concentrations of chlordecone were significantly higher in fishes that usually live at the borders of mangrove (Tukey's HSD, all $p<0.001$ ) like Centropomus undecimalis (concentration max: $628 \mu \mathrm{g} \cdot \mathrm{kg}^{-1}$ ) or Chloroscombrus chrysurus $\left(185 \mu \mathrm{g} \cdot \mathrm{kg}^{-1}\right)$. Fishes from the open sea and the coastal water column presented similar levels of contamination with mean concentrations $\left( \pm \mathrm{SE}\right.$ ) equal to $102.8 \pm 6.4$ and $82.6 \pm 19.8 \mu \mathrm{g} . \mathrm{kg}^{1}$ respectively (Tukey's HSD, $p=0.91$ ). For example, this group of fish was represented by Megalops atlanticus (concentration max: $1760 \mu \mathrm{g} \cdot \mathrm{kg}^{-1}$ ), Caranx latus (365 $\left.\mu \mathrm{g} \cdot \mathrm{kg}^{-1}\right)$, Scomberomorus cavalla $\left(696 \mu \mathrm{g} \cdot \mathrm{kg}^{-1}\right)$ or Harengula humeralis $\left(194 \mu \mathrm{g} \cdot \mathrm{kg}^{-1}\right)$. Finally, fishes occurring in coral reefs and soft bottoms, as Cantherhines macrocerus, Holocentrus adscensionis, Gerres cinereus or Pseudupeneus maculatus showed similar concentrations of chlordecone and were the less contaminated (Tukey's HSD, $p=0.99$ ). The mean concentration of chlordecone ( \pm SE) of fishes usually living in coral reef habitats was $28.7 \pm$ $5.9 \mu \mathrm{g} . \mathrm{kg}^{-1}$ and that of fishes living on soft bottoms was $27.5 \pm 4.2 \mu \mathrm{g} . \mathrm{kg}^{-1}$. 


\section{Discussion}

Before 2008, few studies were done on the contamination of marine organisms by chlordecone in the Lesser Antilles (Bocquené 2002; Bouchon and Lemoine 2003; Coat et al. 2006; Bouchon and Lemoine 2007). Since the first description of a potential contamination in the marine systems, and the establishment of a maximal residue limit (MRL) equal to 20 $\mu \mathrm{g} \cdot \mathrm{kg}^{-1}$ wet weight in the sea products, several campaigns of sampling have been carried out around Guadeloupe and Martinique (Bertrand et al. 2009, 2010; Bodiguel et al. 2011; Bertrand et al. 2013).

The present study is the first compilation of the analyses of chlordecone measured in marine organisms after ten years of surveys in the French Antilles. This study is also the first approach to evaluate the level of contamination of these organisms according to their ecology (trophic groups and habitats).

In Guadeloupe, bananas plantations have been developed in the southeast of the island while fields of bananas in Martinique are located mainly in the northeast. In these areas, located on the slopes of volcanoes, rainfall can reach $4000 \mathrm{~mm}$ per year. Runoff and ground waters, which are important vectors of dispersion of the molecule in the natural environment, end up in the sea and lead to the contamination of marine environment.

In the marine environment, the highest levels of chlordecone measured in fishes were found in zones G01 and G02 in Guadeloupe and zones M01 in Martinique, which are located downstream the contaminated basins. In Martinique, zone M07 is also part of the most contaminated marine areas. This zone is located in the Bay of Fort-de-France. The watershed of that bay collects the water of half the surface of the island and, consequently, an important part of the runoff from banana plantations. Moreover, a large river, flowing from the north of Martinique to that bay, provides high inputs of pollutants in this area. Previous measures have shown that the mean concentration of suspended organic matter of this river

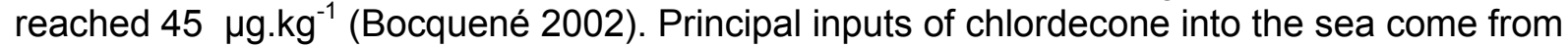
the streams crossing over bananas fields (Cabidoche et al. 2009). Crustaceans were also contaminated in zone G01, G02, M01 and M07 but seemed to be more sensitive to organochlorine pollution. Indeed, even if the number of samples varied between the different studied zones, mean concentrations of chlordecone in crustaceans were higher than the maximal residue limit in several zones (G03, G04, G05, M02, M03 and M05). Bahner et al. (1977) showed that crustaceans like shrimps (Mysidopsis bahia and Palaemonetes pugio) bioconcentrate Kepone up to 11000 times the concentration in the exposure water. Schimmel et al. (1979) demonstrated that crabs like Callinectes sp do not depurate of Kepone after 90 days with Kepone-free diets. On the contrary, in the present study, mollusks appear to be less contaminated than crustaceans or fish, but the number of samples was relatively low for this taxonomic group.

The highest concentrations of chlordecone were measured in samples of fishes that usually live around coastal mangroves. Mangrove is the marine system the closer from the coast and from estuaries. The first hypothesis to explain this contamination can be linked to the structure of the roots of mangrove trees that play a major role in the retention of terrestrial sediments and organic matter. Indeed, a considerable amount of contaminated organic matter could be stocked around mangrove and lead to the contamination of resident fishes. Peters et al. (1997) indicated that one general factor affecting the bioavailability of contaminants is that the organic carbon content of sediments decreased from mangroves to seagrass beds to coral reefs. The second hypothesis could be linked to the location of mangroves, generally in calm and semi-enclosed areas, like the sheltered bays. The sheltered bays or semi-enclosed areas receive direct discharges of chemical from the 
terrestrial ecosystem and are more exposed to chlordecone than the open coast, where terrigeneous flux are dispersed (Loganathan and Kannan 1994; Bertrand et al. 2010).

The exposure of human by chlordecone, especially with the consumption of seafood products, can induce several risks for health, like the risk of cancer prostate or specific impairment in fine motor function in young boys (Schimmel et al. 2010, Boucher et al. 2013). In order to protect the local population from contamination by seafood consumption, the authorities have established several measures, restricting fishing in several marine areas. Thus, in the coastal parts of zones G02, M02, M01 and M07, fishing activities are totally banned. Moreover, a major part of zones G01, G03 and M03 has been classified as areas of fishing restrictions. In those areas, it is forbidden to fish a list of species that were found to be the most contaminated (like crustaceans and piscivorous fishes).

To understand the process of contamination, concentrations have been compared between trophic groups of fishes. The present study shows that detritivores-omnivores were the most contaminated fishes, probably because they are in close contact with the organic matter of the sediment, as it had been demonstrated for crustaceans (Nimmo et al. 1971; Marinucci and Bartha 1982). Indeed, chlordecone is hydrophobic and is known to have a strong affinity to organic matter. Considering the other trophic groups, herbivores and carnivores 1 were the less contaminated while planktivores, carnivores 2 and piscivores showed an intermediate level of contamination. Salvat et al. (2012) found similar results in the Pacific, where the mean concentrations of chlordecone were maximal for detritivore and minimal for herbivores. However, in this study, mean concentrations were very low $\left(<2 \mathrm{ng} \cdot \mathrm{g}^{-1}\right)$ due to the limited use of chlordecone in this region.

Several factors can explain these differences of contamination according to the diet. Carnivores 2 and piscivores can bioaccumulate chlordecone from their preys, as it has been demonstrated in a river trophic web (Coat et al. 2006) and with many other organochlorine molecules (Bahner et al. 1977; Pastor et al. 1996; Borga et al. 2001; Bayen et al. 2005; Coat et al. 2011; Zhao et al. 2014). Moreover, organochlorine molecules have strong affinities with lipids and larger fish like predators contain more fats than smaller fishes (Stout 1980).

Planktivores also showed an intermediate level of contamination, which might be linked to the concentrations in plankton. In Guadeloupe, concentrations measured in plankton varied from 406 to $1530 \mu \mathrm{g} \cdot \mathrm{kg}^{-1}$ in the contaminated marine areas (D. Monti, unpublished data). In the James River, close to the manufacture of Kepone in Hopewell (VA), the highest residues in the estuary were found in zooplankton, which averaged $4800 \mu \mathrm{g} \cdot \mathrm{g}^{-1}$ (Nichols 1990).

The contamination of the marine environment has strong impacts on local fisheries due to the restrictions on fishing activities. Several coastal areas have been closed and fishers have to go far from the coast to work. Even if the campaign realized since 2003 gave valued information on the contamination of fish species and marine areas, more data should be obtained to improve the knowledge of chlordecone pollution in the marine environment.

\section{Acknowledgements}

The present study was conducted in the framework of the French National Program on chlordecone. We gratefully thank the different offices that established, carried out the sampling protocols and gave us the data: Veterinary Services (data from 2008-2010), the Department of Food, Agriculture and Forests (after 2010), the Department of Environment, Land settlement and Housing, the University Antilles-Guyane (UAG) and the French Research Institute for Exploitation of the Sea (Ifremer). The authors express their thanks to the professional fishermen for collecting samples. 
Bahner LH, Wilson AJ, Sheppard JM, Patrick JM, Goodman LR, Walsh GE (1977) Kepone® Bioconcentration, accumulation, loss and transfer through estuarine food chains. Chesap Sci 18: 299-308

Bayen S, Wurl O, Karuppiah S, Sivasothi N, Kee Lee H, Obbard JP (2005) Persistent organic pollutants in mangrove food webs in Singapore. Chemosphere 61: 303-313

Bertrand JA, Abarnou A, Bocquené G, Chiffoleau JF, Reynal L (2009) Diagnosis of the contamination of halieutic fauna by chemical along the coastlines of French Antilles. Surveys 2008 in Martinique and Guadeloupe. Rapport Ifremer, 136 p (in French). http://archimer.ifremer.fr/doc/00000/6896/

Bertrand JA, Bodiguel X, Abarnou A, Reynal L, Bocquené G (2010) Chlordecone in the marine environment around the French West Indies: from measurement to pollution management decisions. ICES, CM 2010, $9 \mathrm{p}$ (in French). http://archimer.ifremer.fr/doc/00014/12511/

Bertrand JA, Guyader O, Reynal L (2013) Characterization of the contamination of the halieutic fauna by chlordecone around Guadeloupe (surveys 2008 to 2011). Rapport Ifremer, 39 p (in French). http://archimer.ifremer.fr/doc/00136/24762/

Bocquené G (2002) Punctual assessment of the presence and effects of pesticides in the coastal environment in Martinique in 2002. Rapport Ifremer, $46 \mathrm{p}$ (in French)

Bocquené G, Franco A (2005) Pesticide contamination of the coastline of Martinique. Marine Pollut Bull 21: 9511-9521

Bodiguel X, Bertrand JA, Frémery J (2011) Transfert of the chlordecone in the trophic foodwebs of commercial marine species in the Lesser Antilles (Chloretro). Rapport fremer, $46 \mathrm{p}$ (in French). http://archimer.ifremer.fr/doc/00036/14684/

Borga K, Gabrielsen GW, Skaare JU (2001) Biomagnification of organochlorine along a Barents Sea food chain. Environ Pollut 113: 187-198

Boucher O, Simard MN, Muckle G, Rouget $F$, Kadhel $P$, Bataille $H$, Chajès V, Dallaire R, Monfort C, Thomé JP, Multigner L, Cordier S (2013) Exposure to an organochlorine pesticide (chlordecone) and development of 18-month-old infants. NeuroToxicology 35: 162-168

Bouchon C, Lemoine S (2003) Level of contamination by pesticides in marine food webs of Guadeloupe and research of biomarkers of genotoxicity. Rapport UAG-DIREN, 33 pp (in French)

Bouchon C, Lemoine S (2007) Contamination of marine organisms by pesticides in the bay of Grand Cul-de-Sac Marin (Guadeloupe). Rapport UAG-DIREN, 39 pp (in French)

Cabidoche YM, Achard R, Cattan P, Clermont-Dauphin C, Massat F, Sansoulet J (2009) Long-term pollution by chlordecone of tropical volcanic soils in the French West Indies: A simple leaching model accounts for current residue. Environ Pollut 157: 1697-1705

Coat S, Bocquené G, Godard E (2006) Contamination of some aquatic species with the organochlorine pesticide chlordecone in Martinique. Aquat Living Resour 19: 181-187

Coat S, Monti D, Legendre P, Bouchon C, Massat F, Lepoint G (2011) Organochlorine pollution in tropical rivers (Guadeloupe): role of ecological factors in food web bioaccumulation. Environ Pollut 159: 1692-1701

Epstein SS (1978) Kepone - Hazard evaluation. Sci Total Environ 9: 1-62

Kermarrec A (1980) Level of contamination of trophic food chains in Guadeloupe: pesticides and heavy metals 1979-1980. Rapport INRA, 155pp (in French)

Huff JE, Gerstner HB (1978) Kepone: a literature summary. J Environ Pathol Toxicol 1: 377-395

Loganathan BG, Kannan K (1994) Global organochlorine contamination trends: an overview. Ambio 23: 187-191 
Marinucci AC, Bartha R (1982) Accumulation of the Polychlorinated Biphenyl Aroclor 1242 from contaminated detritus and water by the saltmarsh detritivore, Uca pugnax. Bull Environm Contam Toxicol 29: 326-333

Multigner L, Ndong JR, Giusti A, Romana M, Delacroix-Maillard H, Cordier S, Jégou B, Thome JP, Blanchet P (2010) Chlordecone exposure and risk of prostate cancer. Am $\mathrm{J}$ Clin Oncol 28: 3457-3462

Nichols MN (1990) Sedimentologic fate and cycling of Kepone in an estuarine system: example from the James River estuary. Sci Total Environ 97/98: 407-440

Nimmo DR, Wilson PD, Blackman RR, Wilson AJ (1971) Polychlorinated Biphenyl absorbed from sediments by fiddler crabs and pink shrimp. Nature 231: 50-52

Pastor D, Boix J, Fernandez V, Albaigés J (1996) Bioaccumulation of organochlorinated contaminants in three estuarine fish species (Mullus barbatus, Mugil cephalus and Dicentrarcus labrax). Mar Pollut Bull 32: 257-262

Peters EC, Gassman NJ, Firman JC, Richmonds RH, Power EA (1997) Ecotoxicology of tropical marine ecosystems. Environ Toxicol Chem 16: 12-40

Salvat B, Roche H, Berny P, Ramade F (2012) Study on the contamination of marine organisms by pesticides from French Polynesia coral reef food web. Revue d'Ecologie 67: 129-148 (in French)

Schimmel SS, Patrick JM, Faas LF, Oglesby JL, Wilson AJ (1979) Kepone ®: Toxicity and bioaccumulation in blue crabs. Estuaries 2: 9-15

Stout VF (1980) Organochlorine residues in fishes from the Northwest Atlantic Ocean and Gulf of Mexico. Fish Bull 78: 51-58

Snegaroff J (1977) Residues of organochlorine insecticides in soils and rivers in the area of banana plantations in Guadeloupe. Phytiatrie-Phytopharmacie 26: 251-258 (in French)

Zhao Z, Wang Y, Zhang L, Cai Y, Chen Y (2014) Bioaccumulation and tissue distribution of organochlorine pesticides (OCPs) in freshwater fishes: a case of study performed in Poyang Lake, China's largest lake. Environ Sci Pollut R 21: 8740-8749 
Table 1 Mean \pm SE (min - max) concentrations of chlordecone in $\mu g \cdot \mathrm{kg}^{-1}$ measured in fish, crustaceans and molluscs samples in the eleven marine zones in Guadeloupe. $\mathrm{n}$ is the number of samples. ANOVAs were performed to test the difference of concentrations between marine zones.

\begin{tabular}{cccc}
\hline Zones & Fish & Crustaceans & Molluscs \\
\hline $\mathrm{n}$ & 1046 & 242 & 143 \\
\hline G01 & $80.9 \pm 20.5(0-1036)$ & $29.0 \pm 9.9(0-167)$ & $29.1 \pm 7.9(0-139)$ \\
G02 & $69.6 \pm 10.2(0-1760)$ & $94.1 \pm 19.2(0-388)$ & $23.7 \pm 8.0(0-186)$ \\
G03 & $13.6 \pm 2.7(0-192)$ & $48.1 \pm 18.1(0-171)$ & $1.1 \pm 0.8(0-7)$ \\
G04 & $32.4 \pm 9.3(0-628)$ & $26.1 \pm 9.9(0-181)$ & 0 \\
G05 & $6.5 \pm 1.9(0-117)$ & $49.0 \pm 11.0(0-300)$ & 0 \\
G06 & $4.6 \pm 1.4(0-240)$ & $5.8 \pm 1.5(0-31)$ & 0 \\
G07 & $2.0 \pm 0.3(0-11)$ & $4.7 \pm 1.8(0-44)$ & $1.5 \pm 0.6(0-3)$ \\
G08 & $4.7 \pm 1.9(0-118)$ & $1.0 \pm 0.4(0-6)$ & $0.9 \pm 0.5(0-3)$ \\
G09 & $3.2 \pm 1.3(0-77)$ & $1.6 \pm 0.9(0-22)$ & 0 \\
G10 & $4.2 \pm 0.9(0-41)$ & $2.4 \pm 0.7(0-9)$ & $1.2 \pm 1.2(0-12)$ \\
G11 & 0 & - & -
\end{tabular}

Results of

ANOVAs $\quad \mathrm{F}_{(10,1035)}=12.4, \mathrm{p}<0.0001 \quad \mathrm{~F}_{(9,232)}=8.1, \mathrm{p}<0.05 \quad \mathrm{~F}_{(9,140)}=5.5, \mathrm{p}<0.05$

Table 2 Mean \pm SE (min - max) concentrations of chlordecone in $\mu \mathrm{g} \cdot \mathrm{kg}^{-1}$ measured in fish, crustaceans and molluscs samples in the ten marine zones in Martinique. $\mathrm{n}$ is the number of samples. ANOVAs were performed to test the difference of concentrations between marine zones. NS: no significant difference.

\begin{tabular}{cccc}
\hline Zones & Fish & Crustaceans & Molluscs \\
\hline $\mathrm{n}$ & 807 & 529 & 14 \\
\hline M01 & $57.6 \pm 9.5(0-696)$ & $732.7 \pm 689.0(0-15200)$ & 0 \\
M02 & $30.5 \pm 6.9(0-705)$ & $130.1 \pm 21.6(0-2549)$ & $1.2 \pm 0.6(0-2)$ \\
M03 & $9.9 \pm 1.7(0-79)$ & $53.9 \pm 9.0(0-1414)$ & $1.7 \pm 1.1(0-5)$ \\
M04 & $1.9 \pm 0.8(0-34)$ & $16.8 \pm 8.5(0-240)$ & 0 \\
M05 & $6.3 \pm 2.4(0-106)$ & $203.3 \pm 114.7(0-1454)$ & - \\
M06 & $7.2 \pm 2.0(0-174)$ & $2.6 \pm 0.8(0-7)$ & 0 \\
M07 & $68.2 \pm 10.5(0-618)$ & $172.5 \pm 93.8(0-1967)$ & $30.2 \pm 9.5(0-89)$ \\
M08 & $5.1 \pm 1.2(0-13)$ & $17.6 \pm 12.4(1-79)$ & - \\
M09 & $6.4 \pm 1.2(0-35)$ & $15.0(15-15)$ & - \\
M10 & $11.3 \pm 6.4(0-325)$ & $18.6(0-171)$ & 0 \\
Results of & $\mathrm{F}_{(9,797)}=11.0, \mathrm{p}<0.0001$ & $\mathrm{~F}_{(9,519)}=2.4, \mathrm{p}<0.01$ & $\mathrm{NS}$ \\
ANOVAs & & & \\
\hline
\end{tabular}




\section{Figure captions}

Fig. 1 Location of the study in the Lesser Antilles and boundaries of marine areas studied around Guadeloupe and Martinique. Terrestrial areas in grey indicate contaminated soil due to previous bananas plantations.

Fig. 2 Mean concentrations of chlordecone $( \pm \mathrm{SE})$ in $\mu \mathrm{gg} \cdot \mathrm{kg}^{-1}$ according to the trophic group of fishes, in the most contaminated areas (G01, G02, M01, M07). C1: carnivores 1, C2: carnivores 2, HB: herbivorous, OMNI-DET: omnivorous and detritivores, PK: planktivores, PV: piscivores. Letters indicate similarities of concentrations between trophic groups, calculated with Tukey's HSD post hoc tests

Fig. 3 Mean concentrations of chlordecone ( \pm SE) in $\mu \mathrm{g} \cdot \mathrm{kg}^{-1}$ according to the preferential habitat of fishes, in the most contaminated areas (G01, G02, M01, M07). Soft bottom: sand and seagrass beds, open sea: pelagic fishes that realize trophic incursions in coastal ecosystems. Letters indicate similarities of concentrations between trophic groups, calculated with Tukey's HSD post hoc tests 


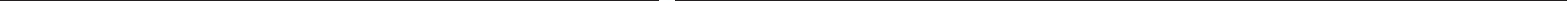




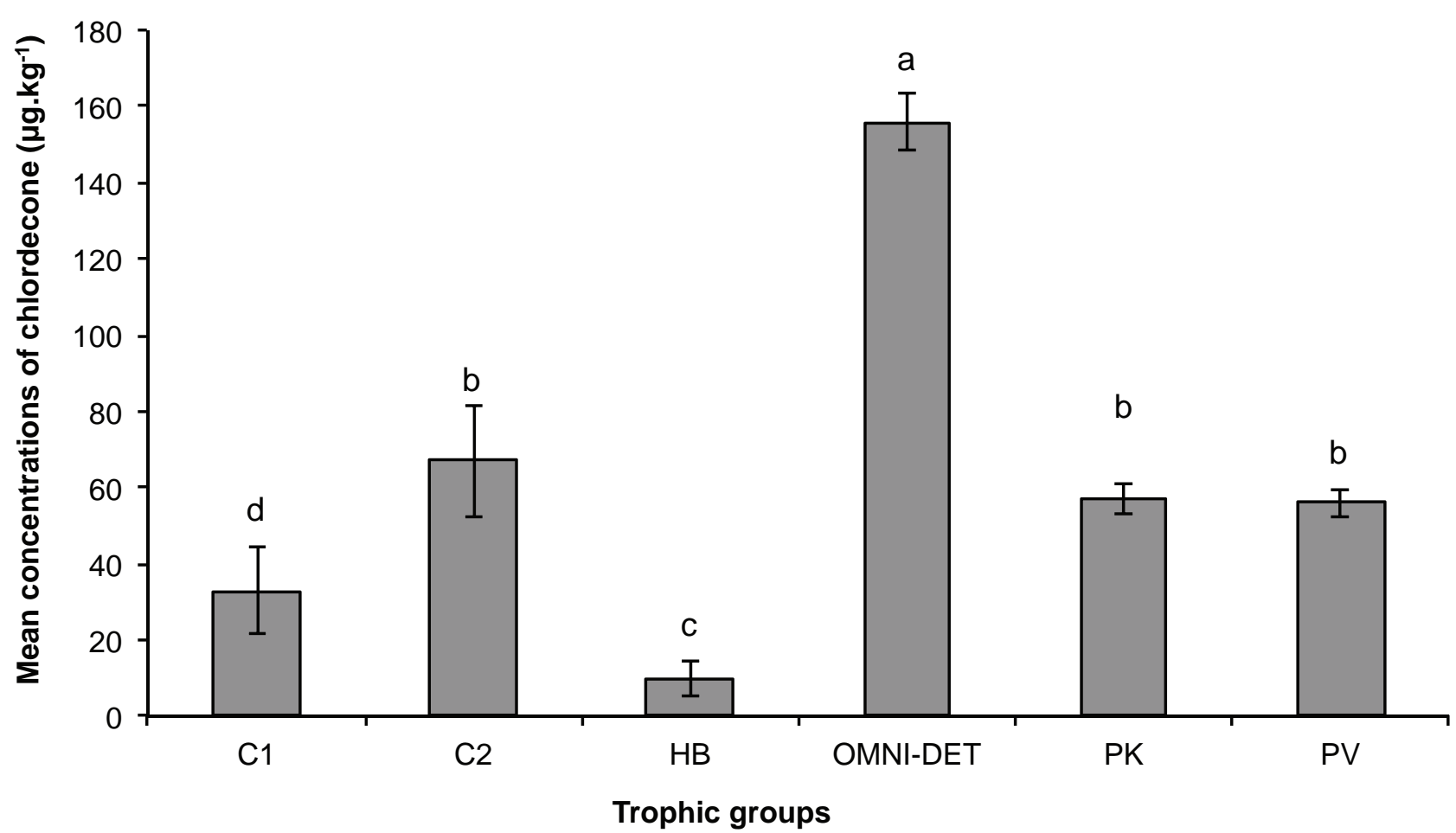




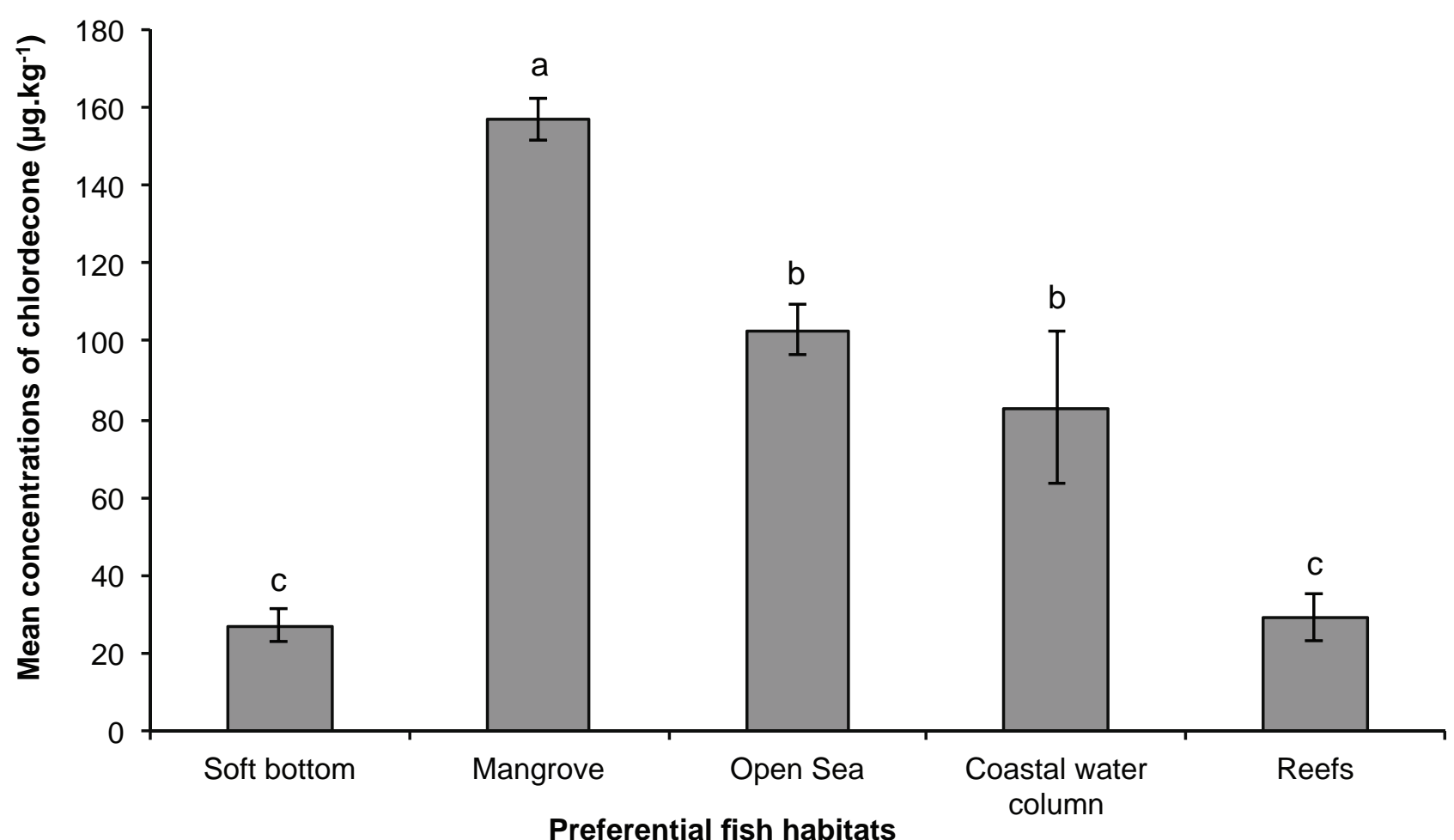

